\title{
Air quality in the vicinity of a governmental school in Kuwait
}

\author{
E. Al-Bassam ${ }^{1}$, V. Popov ${ }^{2} \&$ A. Khan ${ }^{1}$ \\ ${ }^{1}$ Environment and Urban Development Division, \\ Kuwait Institute for Scientific Research, Kuwait \\ ${ }^{2}$ Wessex Institute of Technology, Southampton, UK
}

\begin{abstract}
There is a growing concern in Kuwait for the air quality in the vicinity of schools. The problem exacerbates due to the peak time congestions, which adversely affect the traffic flow, and air quality. Several exceedances of certain primary pollutants have been observed during the peak periods in the country.

Air quality in the vicinity of a governmental school was assessed in March 2006 for a period of two weeks using air pollution monitoring station which recorded continuously various pollutants' concentrations and meteorological variables in five minute intervals. The results show that during the weekdays, the measured pollutants emitted from the road traffic next to the selected school, such as carbon monoxide $(\mathrm{CO})$ and nitrogen dioxide $\left(\mathrm{NO}_{2}\right)$, were always under the allowable limits for Kuwaiti air quality standards except for a single exceedance of $\mathrm{NO}_{2}$ concentration at morning hours. On the other hand, the values of non-methane hydrocarbon pollutants were found to be several times above the Kuwaiti air quality standards throughout the investigated period. The suspended particulates $\left(\mathrm{PM}_{10}\right)$ concentrations have exceeded twice the limits of Kuwaiti air quality standards. A traffic counter was used to record the number of cars in the main road next to the school in fifteen minute intervals for ten days during the monitoring period for air quality. Statistical analysis was used in order to test whether there is any correlation between variations in the $\mathrm{CO}$ concentrations and the traffic frequency during working days' morning and afternoon periods. A relation was developed for predicting the necessary reduction in traffic based on the necessary reduction in $\mathrm{CO}$ concentrations.

Keywords: air pollution, Kuwait, schools, statistical analysis.
\end{abstract}




\section{Introduction}

In Kuwait, the urban population is growing at about 3.4\% per year (Institute of Banking Studies, 2004). This increase in population in addition to the development of urban areas has in turn resulted in massive increase in the demand for transport. Motor vehicles and buses are the only means of road transportation in Kuwait. Road vehicles have increased as shown in Figure 1 with an average growth of $3.0 \%$ annually. The number of buses has not increased from year 1993 till year 2002 (Ministry of Planning, 2003), and its annual growth rate is negligible. Presently, there are 377.2 vehicles for every 1000 persons, which indicates that there are 2.65 persons per car (Institute of Banking Studies. 2004). Motor vehicles and buses cause environmental pollution due to exhaust emissions and tyres abrasion which depend on driving cycles, engine design and condition, fuel composition and air to fuel ratio. The vehicular emissions constitute harmful pollutants that affect the health adversely such as carbon monoxide, particulate matter, nitrogen oxides, and lead. A large proportion of urban pollution is mainly due to road traffic.

According to the Ministry of Education (MOE) in Kuwait statistical data and Ministry of Planning statistics, the school buses are serving approximately 17 to $18 \%$ of students in the governmental schools. Based on 2003/2004 statistics, there are 23,302 students using buses out of 131,597 total students. The rest of students mostly depend on private transportation.

According to various reports (The Ashdon Trust, 1994), it was proved medically that the vehicle air pollutants such as nitrogen dioxide (NO2), carbon monoxide (CO) and particulates (PM10) have pronounced effect on human health as shown in Table1.

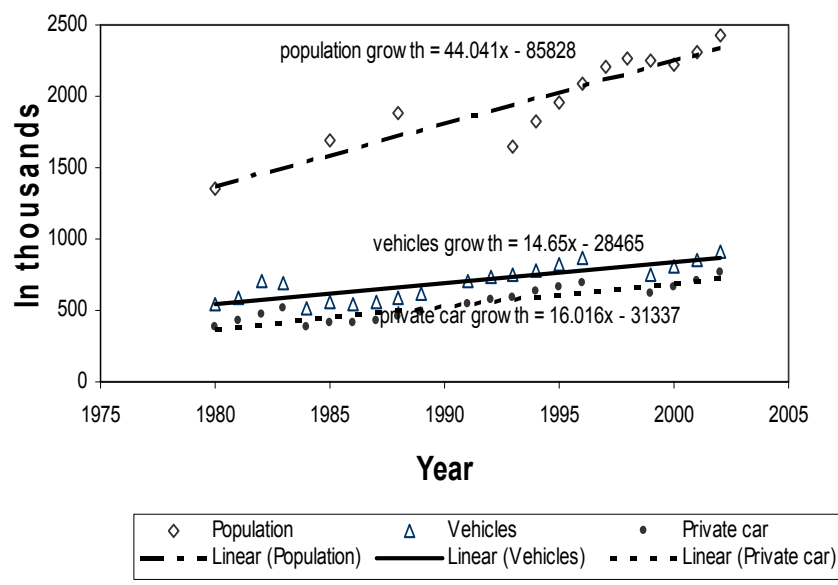

Figure 1: Vehicles in use and the growth of population (after Institute of Banking Studies, 2004). 
Table 1: Health effects of vehicle air pollution.

\begin{tabular}{|c|c|c|}
\hline Pollutant & Source & Health Effects \\
\hline $\begin{array}{l}\text { Nitrogen dioxide } \\
(\mathrm{NO} 2)\end{array}$ & $\begin{array}{l}\text { One of the nitrogen oxides } \\
\text { emitted in vehicle exhaust }\end{array}$ & $\begin{array}{l}\text { May exacerbate asthma } \\
\text { and possibly increase } \\
\text { susceptibility to infections }\end{array}$ \\
\hline $\begin{array}{l}\text { Particulates } \\
\text { PM10, Total } \\
\text { Suspended } \\
\text { Particulates, } \\
\text { Black smoke }\end{array}$ & $\begin{array}{l}\text { Includes a wide range of } \\
\text { solid and liquid particles in } \\
\text { air. Those less than } 10 \mu \mathrm{m} \text { in } \\
\text { diameter (PM10) penetrate } \\
\text { the lung fairly efficiently } \\
\text { and are most hazardous to } \\
\text { health. Diesel vehicles } \\
\text { produce proportionally } \\
\text { more particulates than } \\
\text { petrol vehicles }\end{array}$ & $\begin{array}{l}\text { Associated with a wide } \\
\text { range of respiratory } \\
\text { symptoms. Long-term } \\
\text { exposure is associated with } \\
\text { an increased risk of death } \\
\text { from heart and lung } \\
\text { disease. Particulates can } \\
\text { carry carcinogenic } \\
\text { materials into the lungs }\end{array}$ \\
\hline $\begin{array}{l}\text { Carbon } \\
\text { monoxide }(\mathrm{CO})\end{array}$ & $\begin{array}{l}\text { It is mainly produced from } \\
\text { petrol car exhausts }\end{array}$ & $\begin{array}{l}\text { Lethal at high doses. At } \\
\text { low doses can impair } \\
\text { concentration and neuro- } \\
\text { behavioral function. } \\
\text { Increases the likelihood of } \\
\text { exercise related heart pain } \\
\text { in people with coronary } \\
\text { heart disease. May present } \\
\text { a risk to the fetus. }\end{array}$ \\
\hline Ozone (O3) & $\begin{array}{l}\text { Secondary pollutant } \\
\text { produced from nitrogen } \\
\text { dioxides and volatile } \\
\text { organic compounds in the } \\
\text { air }\end{array}$ & $\begin{array}{l}\text { Irritates the eyes and air } \\
\text { passages. Increases the } \\
\text { sensitivity of the airways }\end{array}$ \\
\hline $\begin{array}{l}\text { Volatile organic } \\
\text { compounds } \\
\text { (VOCs) }\end{array}$ & $\begin{array}{l}\text { A group of chemicals } \\
\text { emitted from the } \\
\text { evaporation of solvents and } \\
\text { distribution of petrol fuel. } \\
\text { Also present in vehicle } \\
\text { exhaust }\end{array}$ & $\begin{array}{l}\text { Benzene has given most } \\
\text { cause for concern in this } \\
\text { group of chemicals. It is a } \\
\text { cancer causing agent } \\
\text { which can cause leukemia } \\
\text { at higher doses than are } \\
\text { present in the normal } \\
\text { environment }\end{array}$ \\
\hline
\end{tabular}

[Reproduced from "How Vehicle Pollution Affects Our Health" (C) The Ashden Trust 1994, p2.] 


\subsection{Study area}

The governmental school which was selected for the study is located at the Mishref area in flat and homogeneous terrain region without any major local air pollution sources. This school is surrounded by Road 57 from north as shown in Figure 2 (www.municipality) which is considered a main street and from the east there is another school under construction. From west and south there are minor streets. The school is surrounded by residential houses and other governmental schools. The schools are adjacent to each other in one lane and there are no school buses at morning or afternoon for students.

The school area is $18,000 \mathrm{~m}^{2}$ and has a parking in the front of the school entrance gate. About 985 students attended this school for year 2005/2006 during the time of monitoring the air quality.

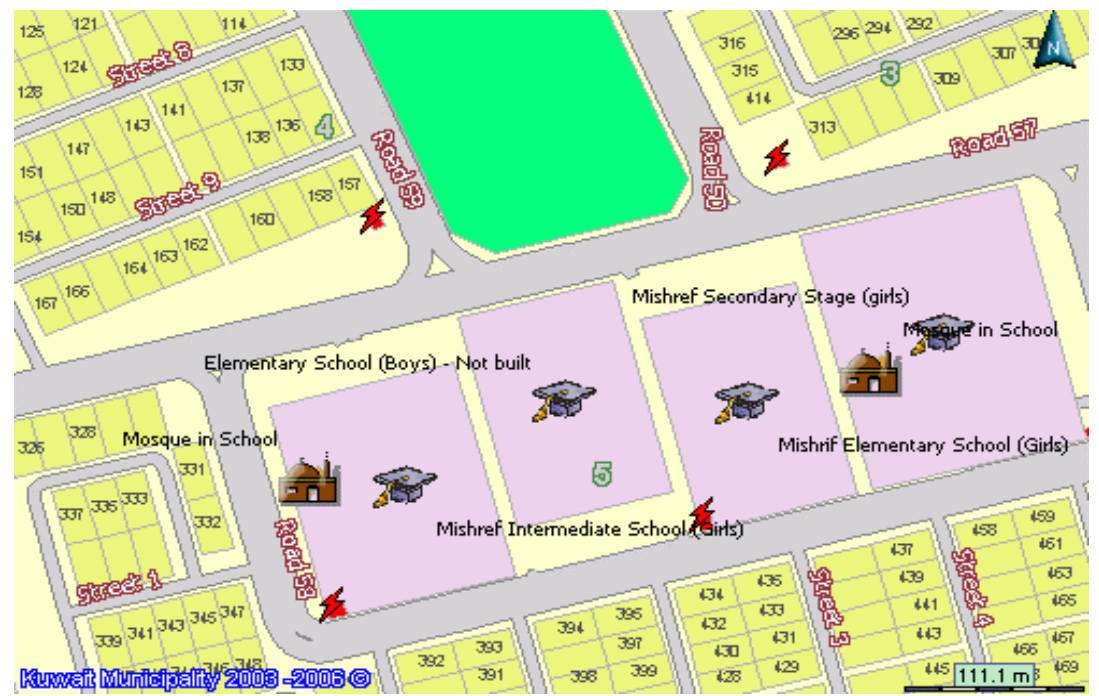

Figure 2: $\quad$ Location of the governmental school at the Mishref area.

\section{Methodology}

Air quality and weather data were recorded at sampling intervals of 5 minutes by Kuwait Institute for Scientific Research (KISR) air monitoring station as shown in Figure 3 for two weeks. The measured data included the concentration of different pollutants such as carbon monoxide $(\mathrm{CO})$, carbon dioxide $\left(\mathrm{CO}_{2}\right)$, methane $\left(\mathrm{CH}_{4}\right)$ and non-methane hydrocarbons, nitrogen oxides $\left(\mathrm{NO}_{\mathrm{x}}\right)$, nitrogen dioxide $\mathrm{NO}_{2}$, and suspended particulates $\left(\mathrm{PM}_{10}\right)$. In addition, the measured data included wind speed, wind direction, solar radiation and ambient temperature. The monitoring station was parked in Mishref area next to the governmental school entrance. A traffic counter was used to record the number of cars in the roads as shown in Figure 4 next to the selected school for every 15 minutes 
throughout the study period. The measurements were taken in March 2006 including weekdays and weekend holidays. Statistical analysis of the recorded data was performed to establish whether there is any correlation between working days' variations in the levels of $\mathrm{CO}$ and the traffic frequency in the vicinity of the governmental school.

\section{Discussion and results}

\subsection{Traffic}

The hourly average weekday and weekend traffic flow profile is shown in Figure 5. The profile of the traffic indicates two peaks during the working days which are related to the opening time of the school and start of working hours in the morning and closing time in the afternoon and end of working hours. At weekends there are no sharp peaks and traffic flow gradually increases followed by slight decrease at afternoon time then minor increase in the evening.

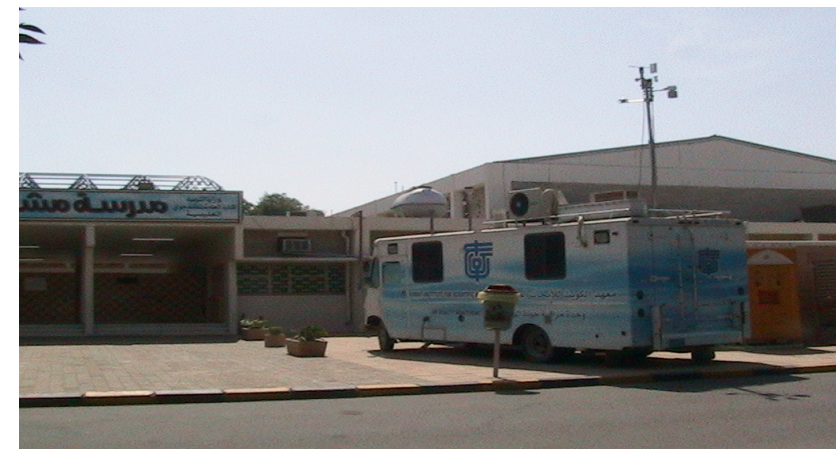

Figure 3: $\quad$ Air monitoring station next to school.

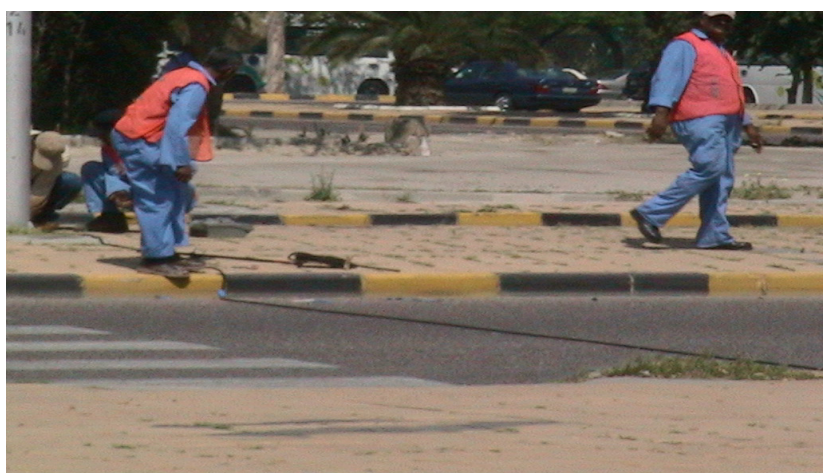

Figure 4: Cars counters on the selected road. 


\subsection{Air quality}

All the measured pollutants' concentrations in the vicinity of the selected school for a period of two weeks were compared with the allowable levels according to Kuwait's air quality standards. The Air Quality Standards (A.A.Q) in the residential areas for Kuwait, Federal US and California states are presented in Table 2. The mean concentration and the maximum and minimum level of $\mathrm{CO}$, $\mathrm{NO}_{2}$, and $\mathrm{PM}_{10}$ pollutants are shown in Figures 6 to 8. The $\mathrm{CO}$ concentrations are always under the allowable limits. The average non- $\mathrm{CH}_{4}$ concentrations are always above the specified limits as shown in Figure 9. $\mathrm{NO}_{2}$ concentration had exceeded the allowable limits 15 times (do you mean on fifteen occassions?) during the study period. The $\mathrm{NO}_{2}$ exceedances are mainly due to road traffic since these values were associated with the increase of $\mathrm{CO}$ levels. Regarding $\mathrm{PM}_{10}$ levels it has exceeded the limits of A.A.Q (on two occassions) during the time of recording.

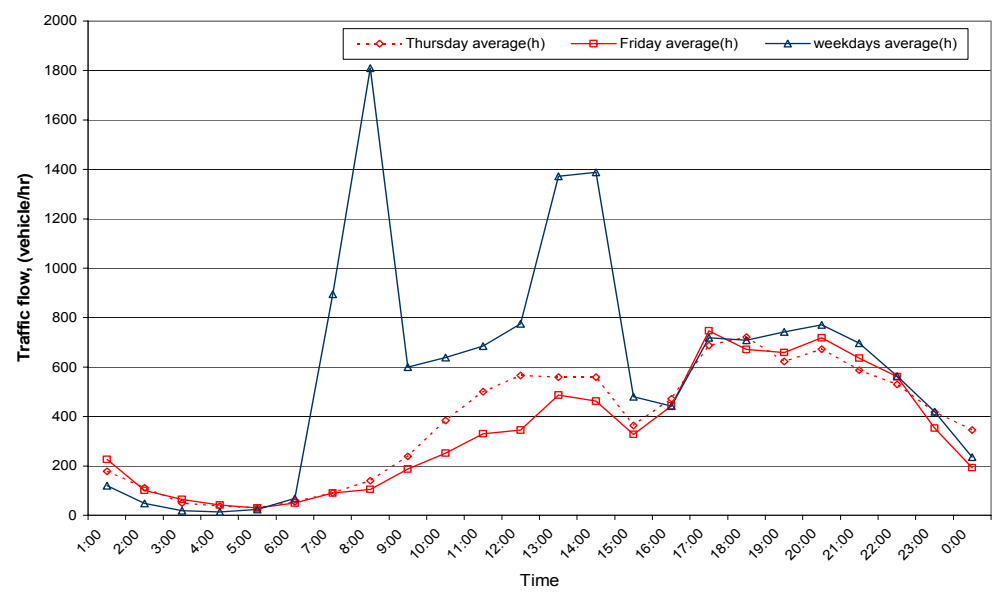

Figure 5: Hourly traffic flow for weekdays and weekend days at the site.

Table 2: The hourly air quality standards for Kuwait, Federal US and California State.

\begin{tabular}{|c|c|c|c|}
\hline Pollutant & Kuwaiti Standard* & Federal Standard & $\begin{array}{c}\text { California } \\
\text { State standard }\end{array}$ \\
\hline Ozone $\mu \mathrm{g} / \mathrm{m}^{3}$ & 157 & 235 & 180 \\
\hline $\mathrm{CO}(\mathrm{ppm})$ & 30 & 35 & 20 \\
\hline $\mathrm{NO} 2(\mathrm{ppm})$ & 0.1 & - & 0.25 \\
\hline PM10 $\mu \mathrm{g} / \mathrm{m}^{3}$ & $350(24$ hours $)$ & $150(24$ hours $)$ & $50(24$ hours $)$ \\
\hline $\begin{array}{c}\text { Non methane } \\
\mathrm{HC}\end{array}$ & $\begin{array}{c}\text { 0.24 ppm for a period } \\
\text { of 3 hours (6-9 AM) }\end{array}$ & - & - \\
\hline
\end{tabular}

*Al-Kuwait Al-Youm. 2001 


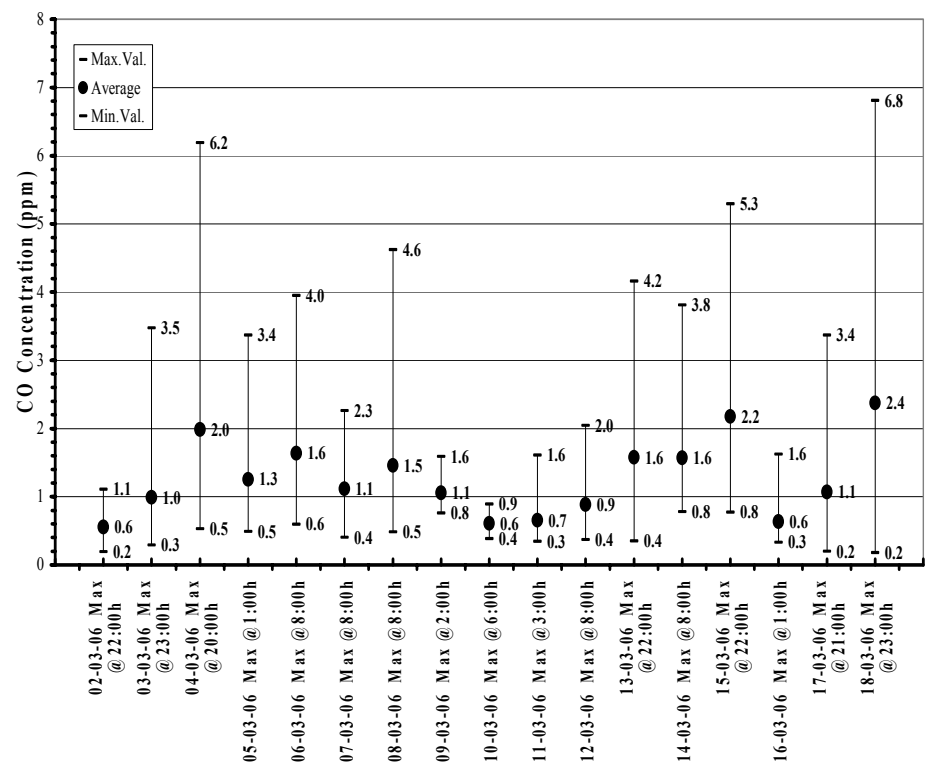

Figure 6: Mean, maximum, and minimum level of $\mathrm{CO}$ concentrations.

\subsection{Statistical analysis}

The recorded data for $\mathrm{CO}$ concentration and cars counts on every 15 minutes during the study period were analyzed taking into consideration the morning hours from 5:00hr $-10: 00 \mathrm{hr}$ and afternoon hours from 11:00hr $-16: 00 \mathrm{hr}$. This strategy was adopted in order to decrease the influence of traffic in the surrounding area and to focus mainly on the traffic in the vicinity of the school, which is the main objective of this research. For the selected time periods, the measured $\mathrm{CO}$ concentrations are plotted against car counts for the 15 minutes intervals. A strong correlation is found in mornings showing $4.4 \mathrm{ppb}$ car while in the afternoon the $\mathrm{CO}$ emissions were $1.3 \mathrm{ppb}$ car depending on the traffic flow as shown in Figure 10. The dispersion of pollutants is slower in morning times than afternoon due to prevailing meteorological conditions, temperature, wind, and inversion layer. The equation, which was obtained from the morning trend of cars versus $\mathrm{CO}$ concentration, was used to predict the effect of reducing the number of cars according to the desired level of $\mathrm{CO}$ concentrations. Figure 11 presents the dependency of $\mathrm{CO}$ concentration reduction as a function decrease in number of cars on the road in the vicinity of the school. This correlation is very important and can be used to regulate the traffic according to desired reduction in air pollution. In this case $40 \%$ reduction in traffic leads to $32 \%$ reduction in $\mathrm{CO}$ concentration. 


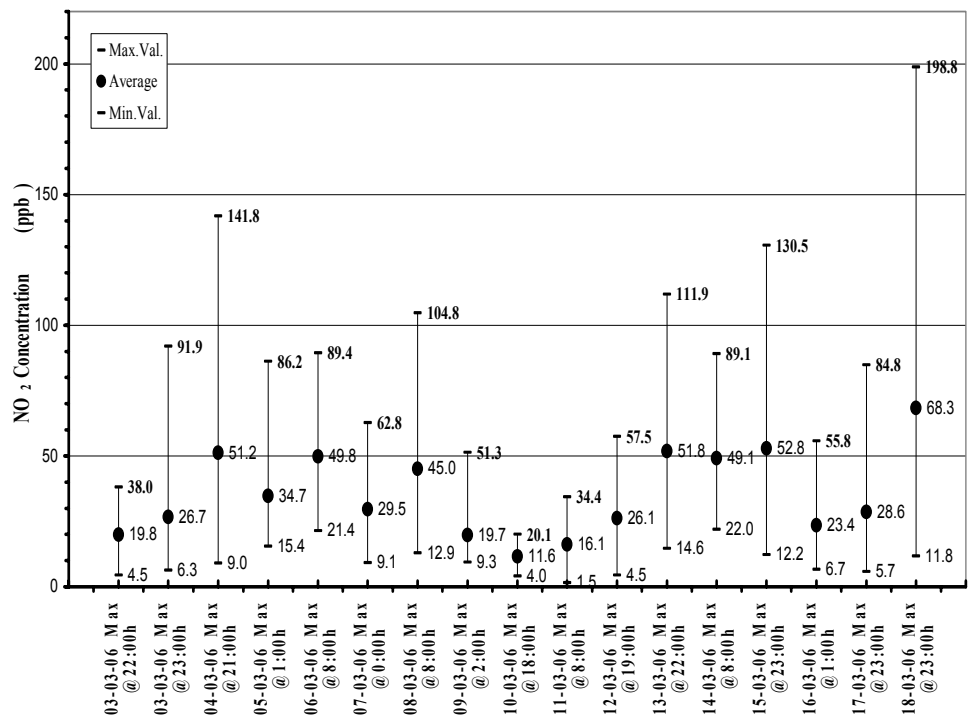

Figure 7: Mean, maximum, and minimum level of $\mathrm{NO}_{2}$ concentrations.

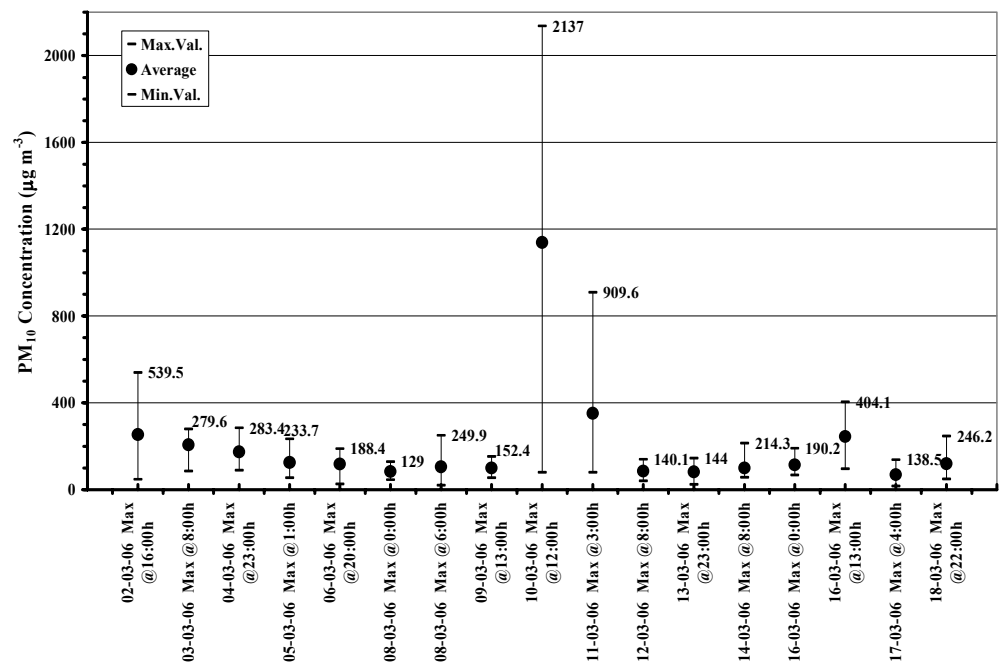

Figure 8: $\quad$ Mean, maximum, and minimum level of $\mathrm{PM}_{10}$ concentrations. 


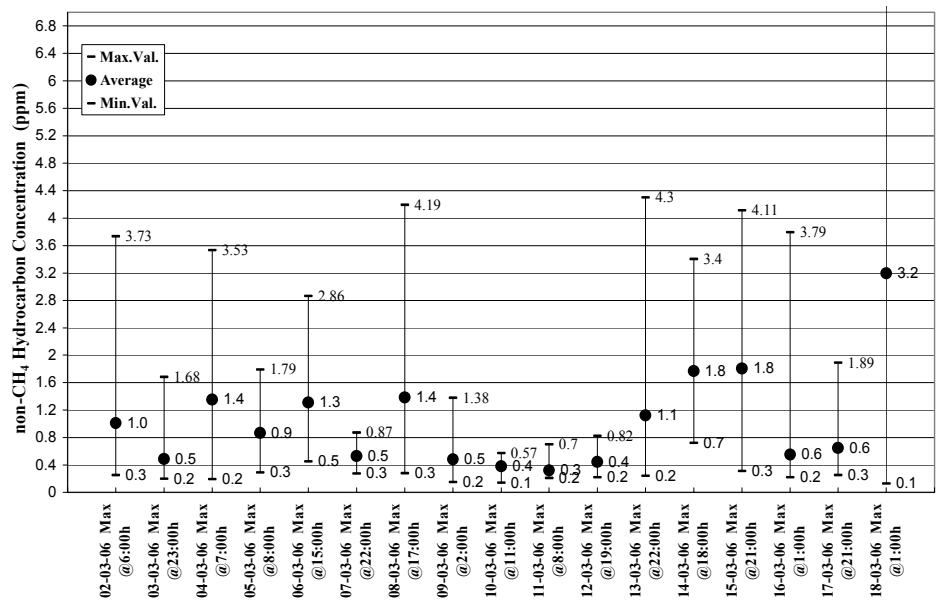

Figure 9: Mean, maximum, and minimum level of non-CH4 Hydrocarbon concentrations.

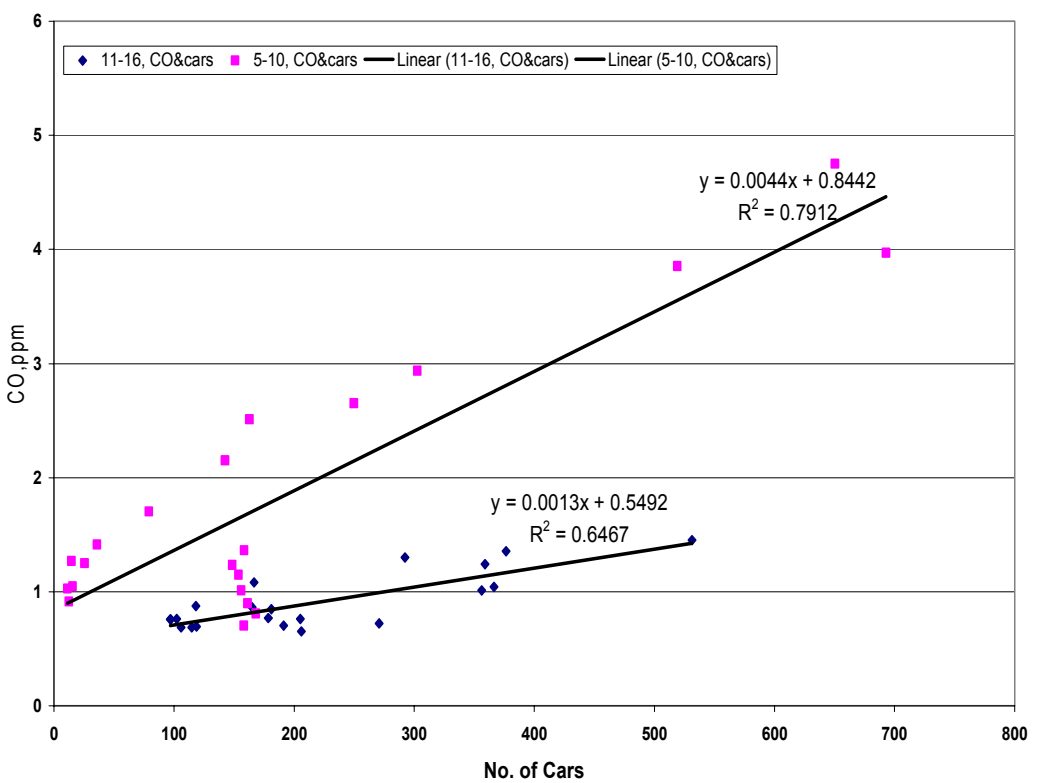

Figure 10: The correlation between $\mathrm{CO}$ pollutant and the number of cars $(5-10=$ morning hours; $11-16=$ afternoon hours $)$. 


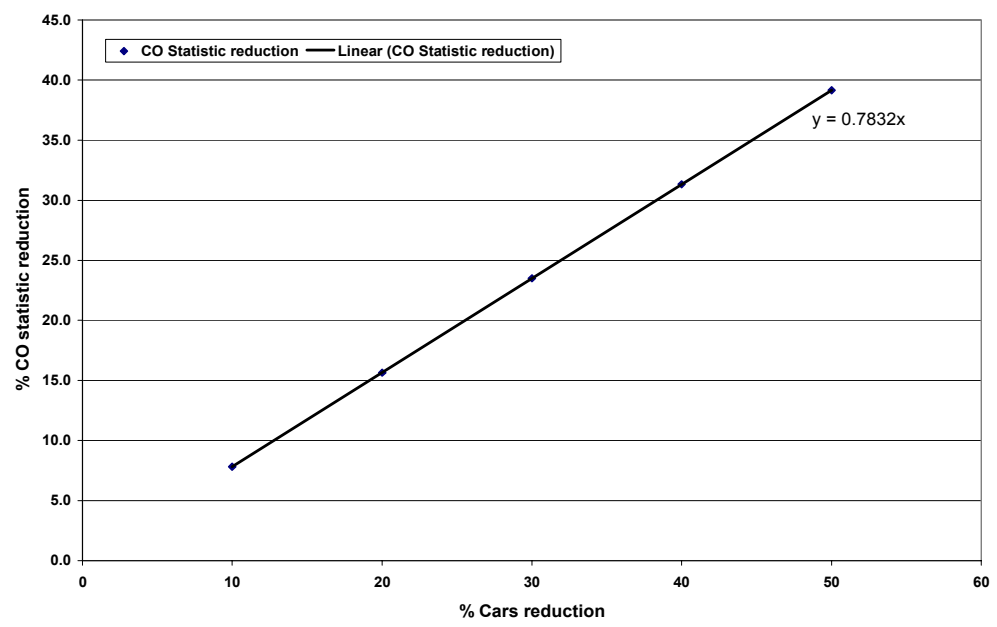

Figure 11: The predicted effect of decreasing the number of cars on $\mathrm{CO}$ concentration.

\section{Conclusion and recommendation}

It is important to maintain high standards of air quality around the schools in order to reduce the effect of traffic pollutants on health of children and their performance. High levels of pollution and traffic conjunctions are recognized as health risk.

Kuwait government should consider public transportation for the governmental schools students to abate traffic conjunction and associated air pollution problems in the country.

Protective measures such as introduction of school buses using superior quality fuel to combat high pollutants emissions are required to achieve good ambient air quality in the country.

\section{References}

[1] Ministry of Planning, 2003

[2] Institute of Banking Studies. 2004. Economic and Financial Data base for Bankers, Research Unit, Kuwait.

[3] "How Vehicle Pollution Affects Our Health" (C) The Ashden Trust 1994, p2

[4] http://www.municipality.gov.kw/gis/ebase_map.htm.

[5] Al-Kuwait Al-Youm. 2001. Annexure No. 533, 2 October 2001, year 47. Ministry of Information (Arabic). 